\title{
Notes on Aeschynanthus (Gesneriaceae) of Sumatra, Indonesia
}

\author{
Sri S. Tjitrosoedirdjo ${ }^{1,2}$, R. Zakaria ${ }^{2}$ Nurainas $^{3}$
}

Key words

Aeschynanthus

Gesneriaceae

Sumatra

\begin{abstract}
An inventory of Gesneriaceae in Sumatra based on herbarium specimens and field trips resulted in 17 genera. The genus Cyrtandra was the most diverse genus, followed by Aeschynanthus. Here we enumerate the species of Aeschynanthus in Sumatra. Distribution and altitudinal notes on 17 species of Aeschynanthus were made and the late Mary Mendum of the Royal Botanic Garden Edinburgh added four more species. The only endemic species of Aeschynanthus in Sumatra is A. chrysanthus; two other species, $A$. albidus and $A$. wallichii, are widely distributed in Sumatra and the rest of Malesia.
\end{abstract}

Published on 30 October 2009

\section{INTRODUCTION}

The first work on the flora of Sumatra began with a publication by Jack in 1820. This was followed by works from various authors in scattered publications. Miquel in 1856 and 1861 described six species of Aeschynanthus, followed by Hallier (1896) who made a list of the Aeschynanthus collections in the Herbarium Bogoriense (BO) and noted five species. Merrill (1934), in his enumeration of the plants collected in Sumatra by W.N. and C.M. Bangham, mentioned six species of Aeschynanthus under the older genus name Trichosporum (see below).

The inventory of the Gesneriaceae in Sumatra resulted in a list of 17 genera (Tjitrosoedirdjo et al. 2003, 2004). The genus Cyrtandra was the most diverse with 61 species, followed by Aeschynanthus.

Aeschynanthus belongs to tribe Trichosporeae. The tribe was first established by Nees (1825) within the family Cyrtandraceae. Nees united the genera Trichosporum D.Don, published in 1822, and Aeschynanthus Jack published a year later (Jack 1823). Both names were in use till 1934, when the name Aeschynanthus was conserved against Trichosporum. However, the tribal name Trichosporeae Nees still stands (Burtt \& Woods 1975).

\section{MATERIAL AND METHODS}

Herbarium specimens of Aeschynanthus from Sumatra in the Herbarium Bogoriense (BO), Andalas University Herbarium (ANDA) and BIOTROP Herbarium (BIOT) were selected and studied. The data were supplemented by additional field collections carried out by the authors in various regions of Sumatra: Tapanuli, Sumatera Utara; Mount Kerinci, Jambi; Mount Singgalang, Sumatera Barat and Bukit Biowa Piluwen, Tes, Bengkulu.

\section{RESULTS AND DISCUSSION}

Seventeen species of Aeschynanthus were recorded for Sumatra (Table 1). The late Mary Mendum added four more spe-

\footnotetext{
1 Department of Biology, Faculty of Science and Mathematics, Bogor Agricultural University, Darmaga, Bogor, Indonesia.

2 SoutheastAsian Regional Center for Tropical Biology (SEAMEO BIOTROP), P.O. Box 116, Bogor, Indonesia.

${ }^{3}$ Andalas University Herbarium, Limo Manis, West Sumatra, Indonesia.
}

cies namely A. brevicalyx Miq., A. caudatus C.B.Clarke, A. flippancei Ridl. and $A$. marginatus Ridl. We were unable to study the specimens of these four species and we had no access to the collecting data, therefore, they are lacking in Table 1.

The plants were found at elevations of 100-2500 m, primarily at the higher altitudes. Sumatera Barat had the highest number of species (15), Sumatera Utara had 8, Aceh 6 and Jambi 6. The other provinces have only five or fewer species. The lowest number was found in Riau province where only two species were found.

There is one endemic species in Sumatra, namely $A$. chrysanthus. Aeschynanthus volubilis (Fig. 1) was originally also regarded as endemic but appears to be present in Java too. Two species of Aeschynanthus, $A$. albidus and $A$. wallichii, are widely distributed in Sumatra and the rest of Malesia. Most of the collections are old, having been made during the colonial era, except for the collections from Sumatera Barat, which were recently collected by the newly established Andalas University Herbarium (ANDA) during an intensive botanical exploration of Sumatera Barat. This might explain why most species were collected in the latter province.

The current situation in Sumatra is a sad picture of natural forest under severe pressure due to a rapid increase in industrialisation. Many forests are deteriorating fast, mainly because of

Table 1 List of Aeschynanthus (Gesneriaceae) species of Sumatra.

\begin{tabular}{rlll}
\hline No. & Species & Province $^{1}$ & Altitude (m) \\
\hline 1. & A. albidus (Blume) Steud. & A, B, SB, SS, SU & $250-1500$ \\
2. & A. angustifolius (Blume) Steud. & A, SB, SS, SU & $100-1300$ \\
3. & A. beccarii C.B.Clarke & SB & 1250 \\
4. & A. chrysanthus P.Woods & SB & 980 \\
5. A. elongatus C.B.Clarke & SB, SU & $1100-2000$ \\
6. & A. fruticosus Ridl. & SU & $1350-1900$ \\
7. A. horsfieldii R.Br. & SB & $950-1000$ \\
8. & A. longiflorus (Blume) A.DC. & J & $1350-1900$ \\
9. A. macrocalyx C.B.Clarke & SB & - \\
10. A. magnificus Stapf & SB & $980-2000$ \\
11. A. obconicus C.B.Clarke & SB & $150-1000$ \\
12. A. pulcher (Blume) G.Don & A, B, J, L, SB, SS, SU & $100-2100$ \\
13. A. radicans Jack & A, B, J, L, SB, SS, SU & $100-2100$ \\
14. A. rhododendron Ridl. & SB & 200 \\
15. & A. speciosus Hook. & A, J, R, SB & $400-2000$ \\
16. A. volubilis Jack & J, L, SB, SS, SU & $800-2500$ \\
17. A. wallichii R.Br. & A, B, J, R, SB, SU & $250-2000$ \\
\hline
\end{tabular}

A = Aceh; $B$ = Bengkulu; $\mathrm{J}=$ Jambi; $\mathrm{L}=$ Lampung; $\mathrm{R}=$ Riau; $\mathrm{SB}=$ Sumatra Barat; $\mathrm{SS}=\mathrm{Su}$ matra Selatan; SU $=$ Sumatra Utara.

(c) 2009 Nationaal Herbarium Nederland

You are free to share - to copy, distribute and transmit the work, under the following conditions:

$\begin{array}{ll}\text { Attribution: } & \text { You must attribute the work in the manner specified by the author or licensor (but not in any way that suggests that they endorse you or your use of the work) } \\ \text { Non-commercial: } & \text { You may not use this work for commercial purposes. }\end{array}$

Non-commercia:

For any reuse or distribution, you must make clear to others the license terms of this work, which can be found at http://creativecommons.org/licenses/by-nc-nd/3.0/legalcode. Any of the above conditions can be waived if you get permission from the copyright holder. Nothing in this license impairs or restricts the author's moral rights. 
Fig. 1 Aeschynanthus volubilis. a. Habit; b. fruit; c. flower; d. corolla; e. gynoecium; f. calyx; g. seed.

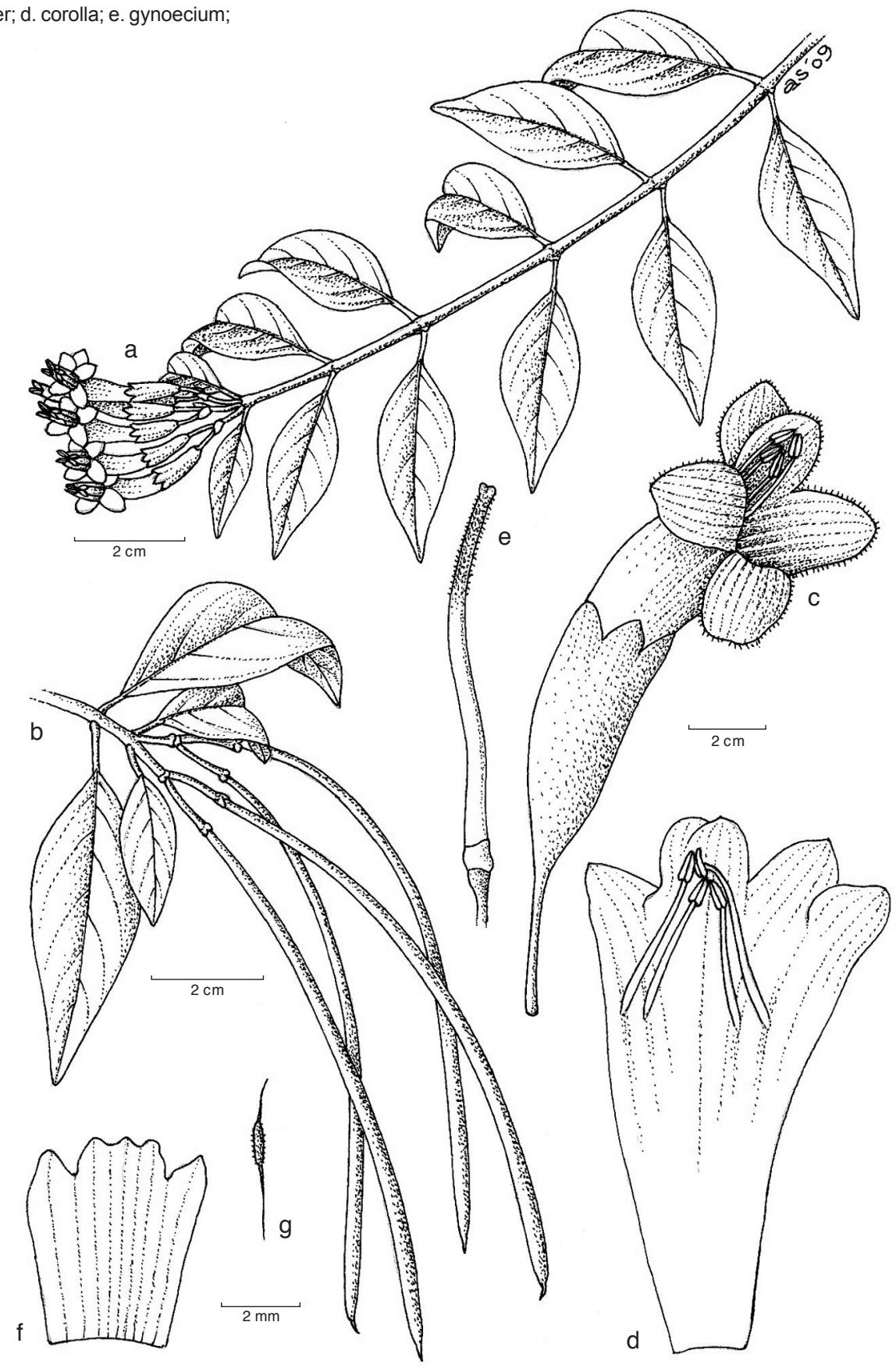

illegal logging that has become a common practice. Aeschynanthus mainly grows as an epiphyte or it is found in the peaty litter of the forest floor where it is hardly visible. The plants are probably vulnerable and presently we are very likely experiencing a loss of Aeschynanthus species due to this unfavourable change in the habitat.

\section{CONCLUSIONS}

There are 21 species of Aeschynanthus in Sumatra. One is endemic and two species are widely distributed in Sumatra and the rest of Malesia.

Acknowledgements The authors wish to thank the director of Herbarium Bogoriense (BO) and Andalas University Herbarium (ANDA) for providing facilities to work in their herbaria. The field work was conducted with financial support by the DIP project SEAMEO BIOTROP.

\section{REFERENCES}

Burtt BL, Woods PJB. 1975. Studies in the Gesneriaceae of the Old World. XXXIX. Toward a revision of Aeschynanthus. Notes from the Royal Botanic Garden, Edinburgh 33: 471-489.

Don D. 1822. Edinburgh Philosophical Journal 7: 85.

Hallier H. 1896. Die Indonesischen Aeschynanthusarten des Herbariums zu Buitenzorg. Natuurkundig Tijdschrift voor Nederlandsch-Indië 56: 333346.

Jack W. 1820. The Malayan Miscellanies. Bencoolen

Jack W. 1823. On Cyrtandraceae, a new natural order of plants. Transactions of the Linnean Society of London 14: 23-44.

Merrill ED. 1934. An enumeration of plants collected in Sumatra by Walter N. and C.M. Bangham. Contributions from the Arnold Arboretum of Harvard University 7.

Miquel FAW. 1856. Flora van Nederlandsch Indië 2: 716-722. Van der Post, Amsterdam.

Miquel FAW. 1861. Flora van Nederlandsch Indië, eerste bijvoegsel: 238, 563, 564. Van der Post, Amsterdam.

Nees von Esenbaeck F. 1825. Flora 8: 143. Regensburg.

Tjitrosoedirdjo SS, Radhiah, Hidayat AS, Nurainas, Tamin R. 2004. Gesneriaceae of Sumatra. Internal report, SEAMEO BIOTROP.

Tjitrosoedirdjo SS, Radhiah, Nurainas, Tamin R. 2003. Gesneriaceae of West Sumatra. Internal report, SEAMEO BIOTROP. 